\title{
ASEAN's Regional Business Innovation Through Digitization of Supply Chain
}

\author{
Tian Nur Ma'rifat ${ }^{1}$, Amal Fathullah Zarkasyi ${ }^{2}$, Muhamad Fajar Pramono ${ }^{3}$, \\ Yoyok Suyoto Arief ${ }^{4}$, Dihin Muriyatmoko ${ }^{5}$ \\ $\left\{\right.$ tiannurm@unida.gontor.ac.id ${ }^{1}$, amal@unida.gontor.ac.id ${ }^{2}$, \\ mfpramono@unida.gontor.ac.id ${ }^{3}$, yosa@unida.gontor.ac.id ${ }^{4}$, dihin@unida.gontor.ac.id $\left.{ }^{5}\right\}$ \\ University of Darussalam Gontor, Siman Road Km.6, Siman, Ponorogo, East Java, \\ Indonesia ${ }^{1,2,3,4,5}$
}

\begin{abstract}
In 2015, the ASEAN Economic Community (AEC) was established for economic integration. There are some issues headed by ASEAN to implement AEC. The problems faced by this region is it has various development stages of its member countries. The purpose of this paper is to synthesize information from publications related to policy in the regional area. It also analyses how ASEAN boost its economic competitiveness by supply chain innovation. This study applies for a literature review on the studies about the development of trade policy and technology sector of ASEAN. The result of this paper is it recommend implementation strategy for digitization of supply chain on region and industry level. This paper concludes that digitization of supply chain enhances business performance by governance support. Future work implied in this study is empirical analysis in government performance in supply chain integration.
\end{abstract}

Keywords: Supply Chain, Digitization, Business, Policy

\section{Introduction}

The Association of Southeast Asian Nations (ASEAN) is a regional economic organization aimed at promoting economic growth and regional stability among its members. ASEAN is an essential focal point of manufacturing as well as trade in the world. The increase for the consumer market in this region is also included in the fastest one among other areas. For boosting the economic aspect of ASEAN, ASEAN leaders agreed to establish the ASEAN Economic Community (AEC) in 2015.

ASEAN is a diverse group that consists of different markets, varying economic development stages, cultures, and geographical condition. Those conditions make it one of the most competitive regions in the world today. The diversity of those characteristics which are : 
- Geographic Area

ASEAN countries vary in sizes. Indonesia is the largest country which has an area around two thousand times more than the size of Singapore. Geographically, ASEAN is a region consist of archipelago nations, continental lowland, plateau, and mountains. These conditions emphasize the additional coverage cost to enlarge business strategies among ASEAN member countries.

- Population

Indonesia is the Highest populated nations among ASEAN members. The second position in the Philippines. Viet Nam is also highly filled with 87.8 million people. By those elevating number of inhabitants, ASEAN becomes a potential market for other regions to sell their products.

- Urbanization

Due to globalization, the economy has shifted from an agriculture-based to an industrybased. Singapore is most urbanized with 100 percent urban population. On the other hand, Cambodia was mostly countryside area with a percentage of the urban population was around $21 \%$ in 2010 [1]. Urbanization stimulates economic growth because the size, density, and diversity of urban population lead to competitive labor cost and economies of scale business.

- $\quad$ GDP (Gross Domestic Product)

Indonesia and Vietnam are nations with a higher value of GDP than other ASEAN members in 2017. On the contrary, Singapore states in the lowest GDP, since it has a limited area for production activities. GDP growth in a region indicates potential economic strength which can be affected by domestic demand, trade policy, and production capability in that area.

Based on the challenge facing ASEAN above, this paper talks on synthesizing factors affecting business performance in this region and elaborating trade policy related to the digitization of the supply chain as regional business innovation. Because less of publication that argued individually change of supply chain in geographical scope, this paper presents a review of the main idea about the digitization of the supply chain in ASEAN's local policy. Previous research related to the supply chain in geographical scope discussed research in logistics network in Africa [1]. That paper described supply chain issues representation in developing countries such as Africa without examined more regional policy. Other paper investigated regional business innovation. It focused on complex adaptive system governance in the supply chain to respond to the need of the mining industry [2]. It did not recommend notably about the digitization of the supply chain.

The aims of this study are firstly to synthesize information from previous publications related to supply chain policy of ASEAN. The other purpose is to recommend ASEAN's trade policy about the digitization of the supply chain to elevate regional business innovation. The questions for this paper are as follows.

$\mathrm{RQ}_{1}$. How can the scanning of supply chain influence ASEAN's business innovation?

$\mathrm{RQ}_{2}$. What is the recommendation for applying digitization of supply chain in ASEAN?

$\mathrm{RQ} 3$. What is the literature gap of this paper? 


\section{The concept of Digital Supply Chain}

\subsection{Supply Chain}

We started to discuss the definition of the supply chain. The supply chain, which is also defined as logistics network, is a network between parties that change essential commodity (upstream) into the good finished product (downstream) which adds value for customers [3]. Based on Christopher from his book, the definition of the supply chain could more accurate as a network which mutually cooperates as well as connected and dependent upon one another party. Those involved in the supply chain are responsible for the process of the product [4]. Waters [5] added each party of supply chain contributes to the process of converting raw materials into the end product. Figure 1 shows supply chain activities by linking upstream activities and downstream activities.

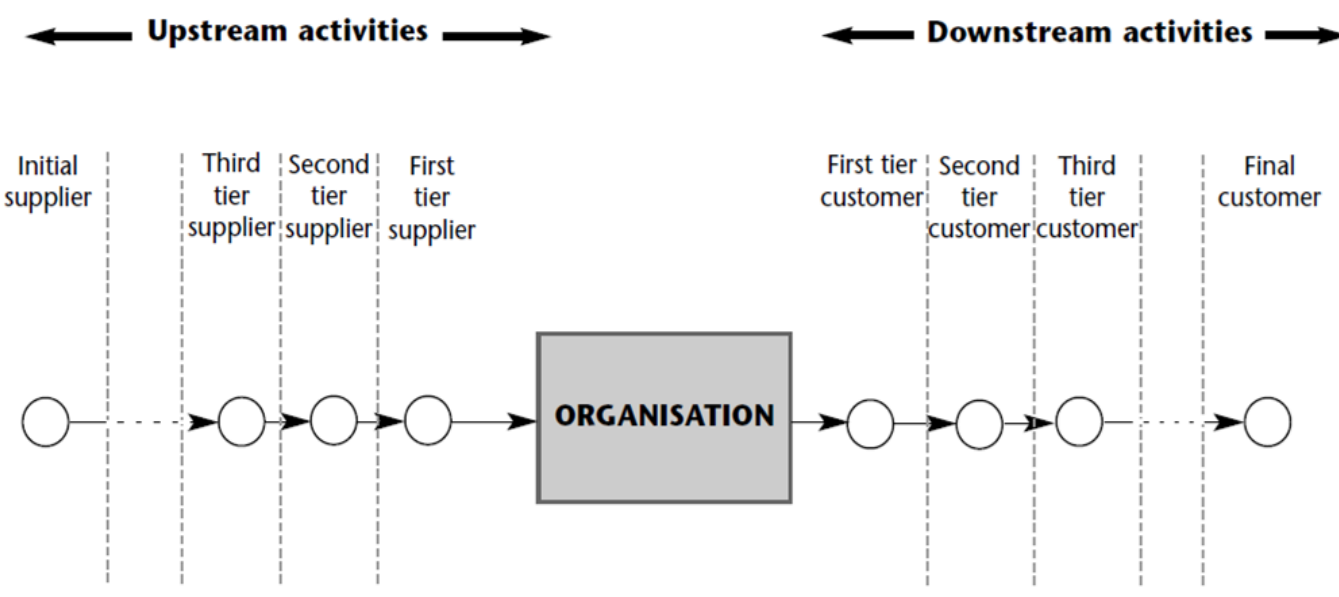

Fig 1. Supply Chain Activity [5]

A more detailed explanation from Waters [5] that upstream activity is a buy-side activity carried out by a manufacturing organization in obtaining material to be processed in the manufacture. Meanwhile, downstream operations are activities operated by companies to distribute their finished products (sell side) [5].

\subsection{Digital Supply Chain}

Business interaction among regional area today is more tight and competitive. Every business innovation in industry related to utilizing smart technologies. This trend sometimes is called Industry 4.0. This phenomenon uses the internet as a trigger. It helps humans communicate with machines through Cyber-Physical-Systems (CPS) across large networks [6]. The changing condition brings business and manufacturing environment into Industry 4.0 which has many impacts on the whole supply chain. Interconnectivity and transparency between suppliers, producers, and customers are essential to be accelerated. It could be implemented when the order is sent until the end-of-life of the product. According to IBM, the supply chain in the future consists of the three technology-based drivers are instrumented, interconnected, and use intelligent [7]. First, "instrumented" means supply chain data would be equipped with 
sensors, RFID, GPS, and other devices [7]. Second, "interconnected" in other literature means whole supply chain parties, are all connected in a smart supply chain, including assets, IT systems, and products [8]. Using the "Intelligent" factor was defined as utilizing a smart system which assists decision maker in making a simulation for various constraint and solution [7]. The other author explained the application of the intelligent system. This hybrid model is needed for demand forecasting in the retail industry [9].

\section{Methodology}

There are many approaches or methods to review the literature with purpose to discuss a topic. The first method in writing a literature review is a narrative review. The aim of this method is to form a bridge among empirical articles and research publications within a related issue [10]. It gives reader conclusion of scope and theoretical level that empirical research paper cannot usually reach [10]. The gap of the narrative literature review is in the existence of empirical studies discussed in this method which could strengthen a line of conclusion in the paper. Another technique is meta-analysis which summarizing, combining and statistically analyzing empirical studies on the subject [11]. Meta-analysis could be used to design new research from the findings of prior studies and also to support evidence-based policy [12]. According to paper reviewed about supply chain management, content analysis is a method that can be used in both quantitative and qualitative data analysis [13]. The technique used in this paper was content analysis. It provided a broader discussion with the flexibility to the researcher for synthesizing complex information related to a topic. By using content analysis, there is also allowed for using qualitative and unstructured data such as interviews or web-based documentary research [13]. Since it was used in the previous publication, content analysis consists of three steps. There are the analysis of articles, the definition of content within each category, and identify research gaps from previous literature [11].

\section{Findings}

\subsection{ASEAN's Business Innovation through Supply Chain Integration}

ASEAN consist of various development stages of its member countries and geographical condition which is a grouping of archipelago nations. Based on data from Mc Kinsey in 2014, the number of ASEAN countries which have low, middle income more than the intermediate upper[14]. The nation members included in high-saving economies are such as Singapore, Malaysia, and Brunei. In contrast, countries such as Cambodia, Laos, and the Philippines are in low-saving economies. Various production facilities and networks are dispersed throughout the entire region. Because of different levels of development among ASEAN members, the efficient and sophisticated flow of inputs to production could be assured [14]

For answering $\mathrm{RQ}_{1}$ "How can digitization of supply chain influence ASEAN's business innovation?", This paper synthesized points and findings from previous journals and also webbased publications related to trade policy of ASEAN. The analysis started with the point about how vital business innovation today in regional scope. Business innovation is a notable step for facing the changing global economy because of the higher demands of computing technology and more active transparent global trading [15]. Regional business innovation stated in the previous publication could carry out the global competition for the members of the collective 
economic community [16]. Furthermore, it proposed a model for the regional enterprise support system. This image consists of governance policy, technology agency, innovation research and support system for evaluating business performance (Figure 2) [16].

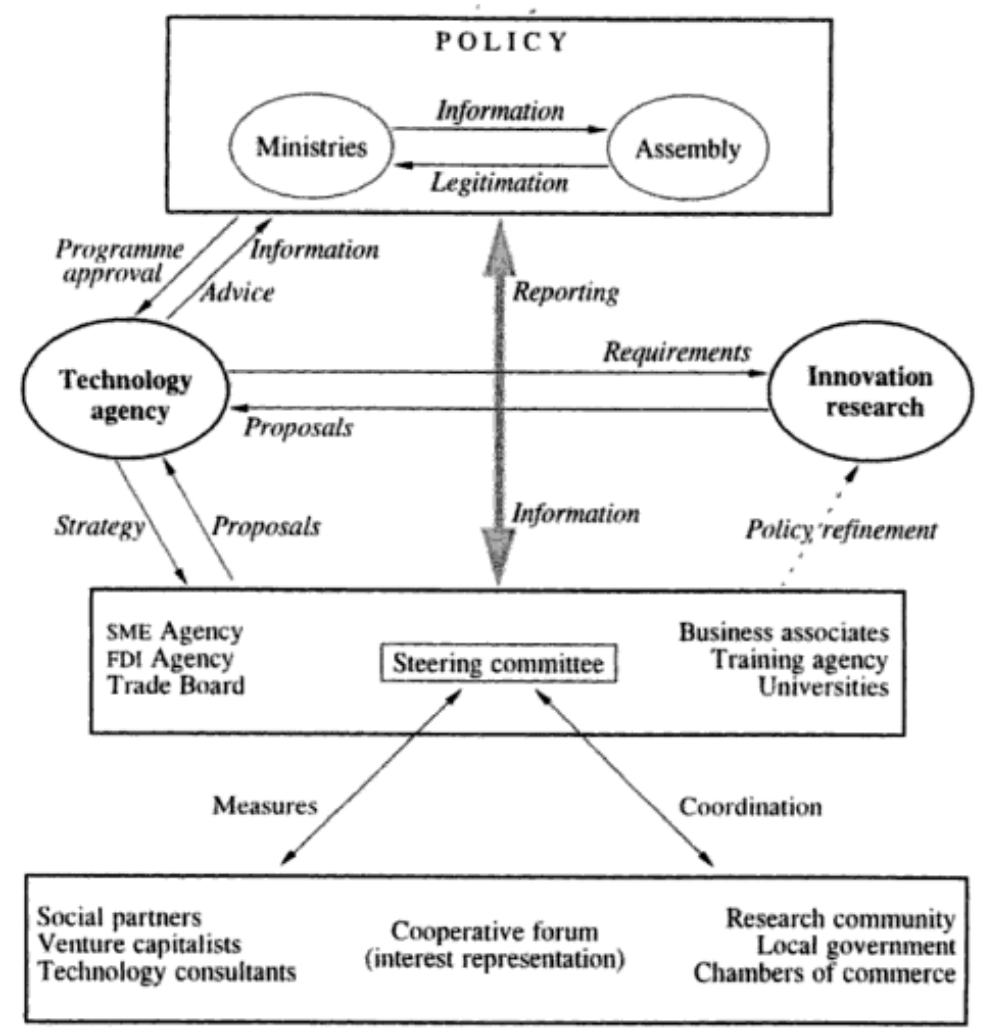

Fig 2. A Regional Enterprise Support System Model[16]

After discussing the definition of regional business, this paper focused on ASEAN policy related to supply chain innovation. The initial step for elevating ASEAN's regional business potential is from the accomplishment of AEC by 2020. The implementation of single market through AEC allows costless trade as well as free mobility of labor and capitals [17]. Megafactory countries in Asia such as Japan, China, and Korea also have signed economic integration with ASEAN which resulting in the signature of the ASEANChina Free Trade Area framework in 2002. The China-ASEAN FTA started to operate in 2010. Free trade area policy impacted firms which began to relocate production abroad. Therefore the domestic value-added gross exports in the manufacturing sector decreased in all countries [18]. The system of China, Japan, and Korea to shift their product into assemblage type and spread the location of their intermediates raw material production to ASEAN countries because the amount of production cost was less than another region. This phenomenon also has led multi-national companies in ASEAN for adopting production strategy. The arrangement involves horizontal and vertical multi-plant 
operations in two or more ASEAN countries for strategic and economic reasons. Cope with that condition; supply chain integration is needed.

\subsection{Policy for Implementation of Supply Chain Digitization in ASEAN}

The recommendation for applying digitization of supply chain in ASEAN urged to be formulated $\left(\mathrm{RQ}_{2}\right)$. Two side approaches have to be done from the governance side as top-down approach and also the industry side as a bottom-up approach.

\section{Industry Side Approach Policy}

Utilization of digital supply chain in industry level according to previous literature is determined by some critical areas of technologies. There are integrated planning system, logistics visibility, smart procurement, and warehousing.

- Integrated Planning System

By utilization of Integrated Planning and control system, signals that sent from supply chain network and alerted all to issues affecting supply or demand [19]. Several models have proposed for integrated planning such as distributed generation integrated with load response [20], planning optimization [21], and static scheduling method [21].

- Logistics Visibility

Chain visibility is majorly influenced by effective "track and trace" system that allows players to determine the status of any given shipment of goods at any point in its travels [19]. Logistic visibility has been implemented in China for building traceability system in the agriculture supply chain by using Blockchain technology and RFID [22].

- Smart Procurement and Warehousing

Digitization of procurement will impact on supply chain cost efficiency and faster delivery. The company needs to connect more closely with suppliers by using big data tools for supporting the planning process, and supplier risk [19]. Procurement 4.0 contributes to improving the organizational supply chain to satisfying customized and innovative demands [23]. In further warehousing system, transportation will be integrated with warehouse management system which is more intelligent, for optimizing just-in-time and just-in-sequence delivery [19]. Smart warehouse management will utilize Internet of Things (IoT), supported with hardware, such as a handheld electronic label, barcode readers and fixed readers and also software, such as a host management system and electronic shelf tags [24]. For more expert implication, smart warehousing can use Web of Things (WoT) to deliver a real-time depiction on the Web [25].

\section{Governance Side Approach Policy}

Revolution of the supply chain in industry level give the main impact for regional policy as industrial revolution 4.0 does not recognize national borders. That condition pushes regional cooperation, and ASEAN through AEC need to upgrade its approach to local governance policy. For the implementation of the digital supply chain in the local area, trade policy among ASEAN members have to set under the vision of AEC. Recommendation of regional strategy retrieved 
from journals, year of publication, publishers, and data analyst which support the implementation of supply chain digitization, as seen in Table 1.

\subsection{Identifying Literature Gap}

This study provides a review of the literature focused on the implementation of supply chain digitization. To begin, there are a few numbers of publication which discussing policy making to build a supply chain network in ASEAN. If we searched keyword in google scholar sorted by date about supply chain in ASEAN, we could see the result that papers mostly talked about supply chain performance. Moreover, if we used keyword "digital supply chain" in those publication search engine, the most relevance and newest topic resulted from this search is blockchain technology, tourism supply chain agility and service supply chain. Digitization of the supply chain is a technological revolution which urgently applied throughout all parties in the chain. Toward disruptive business competition nowadays, a company which intends to win that competition have to be the response by enlarging their business to regional and more for global scale. For building a robust supply chain network which spread globally, policy-making for local as well as industrial level need to be formulated simultaneously. A publication which depicts regional policy in digital transformation discussed that European government had established a procedure for supporting industry 4.0 [26]. All major stakeholders and parties in the industry have a responsibility in the field of digitization. Briefly, this paper served discussion about policymaking in regional area comprehensively.

Table 1. Regional Policy for Implementation of Supply Chain Digitization

\begin{tabular}{|c|c|c|c|}
\hline Author & $\begin{array}{l}\text { Publication } \\
\text { Year }\end{array}$ & Policy & $\begin{array}{l}\text { Implementation for Supply Chain } \\
\text { Integration }\end{array}$ \\
\hline $\begin{array}{c}\text { Wattanapruttipaisan } \\
\text { [27] }\end{array}$ & 2007 & $\begin{array}{l}\text { Appointment of } \\
\text { ICT Equipment } \\
\text { and Logistics as } \\
\text { Priority } \\
\text { Integration } \\
\text { Sectors (PIS) }\end{array}$ & $\begin{array}{l}\text { - Nontrade Costs } \\
\text { - Exacting tariff packages, Rules of } \\
\text { Origin, and technical standards for PIS } \\
\text { commodities } \\
\text { - Research and empowerment of local } \\
\text { firm to upgrade process creativity in the } \\
\text { electronic-related sector. }\end{array}$ \\
\hline $\begin{array}{l}\text { Asian Development } \\
\text { Bank [19] }\end{array}$ & 2017 & $\begin{array}{l}\text { ASEAN through } \\
\text { AEC encourage } \\
\text { Asian } \\
\text { Government to } \\
\text { implement } \\
\text { blockchain } \\
\text { technology }\end{array}$ & $\begin{array}{l}\text { - Digitized transaction among SME's for } \\
\text { providing sophisticated and efficient } \\
\text { microfinance } \\
\text { - Block-chain based platform for } \\
\text { equitable energy supply } \\
\text { - Develop policies and programmes to fuel } \\
\text { entrepreneurship by using block-chain } \\
\text { based marketplace }\end{array}$ \\
\hline $\begin{array}{c}\text { ASEAN Secretariat } \\
\text { [28], Bhattacharyay } \\
\text { [29] }\end{array}$ & $\begin{array}{l}2014, \\
2010\end{array}$ & $\begin{array}{l}\text { ASEAN } \\
\text { established } \\
\text { cooperative } \\
\text { plans in ICT } \\
\text { through the e- } \\
\text { ASEAN } \\
\text { Agreement }\end{array}$ & $\begin{array}{l}\text { - Develop information infrastructure } \\
\text { - Encourage and simplify regulation of } \\
\text { investments in ICT products and } \\
\text { services } \\
\text { - Facilitate the increase of e-commerce }\end{array}$ \\
\hline
\end{tabular}




\section{Conclusions and Recommendations}

This paper presented a literature review which discusses regional policy in ASEAN. This paper also constructed a recommendation for the implementation of the digital supply chain in ASEAN. Digitization of Supply Chain improves regional business performance for more efficient by the governance support system. Implementation strategy for scanning of the supply chain should be carried out from regional governance policy and also industry policy.

There is also still a lack of empirical study about how far digitization of supply chain implemented in ASEAN governance practices and how industry responses for that. Recommendations for future research are listed below.

- An observational study for implementation of supply chain digitization in ASEAN.

- Research about ASEAN governance performance for digitization of supply chain.

- Study about the environmental and social impact from the digitization of the supply chain in ASEAN.

\section{Acknowledgments}

The author presented the paper in the International Conference on Business, Law, and Pedagogy 2019. We thank the University of Darussalam Gontor for fully funding of paper presented at that conference.

\section{References}

[1] J. El Baz, I. Laguir, and R. Stekelorum, "Logistics and supply chain management research in Africa: A systematic literature review and research agenda," International Journal of Logistics Management, 2018.

[2] L. Statsenko, A. Gorod, and V. Ireland, “A complex adaptive systems governance framework for regional supply networks," Supply Chain Manag., 2018.

[3] A. Harrison, R. Hoek, and H. Skipworth, Logistics management and strategy: competing through the supply chain. 2014.

[4] C. Martin, Logistics \& Supply Chain Management. 2011.

[5] D. Waters, Logistics: An introduction to supply chain management. 2003.

[6] M. Brettel, N. Friederichsen, and M. Keller, "How virtualization, decentralization and network building change the manufacturing landscape: An industry 4.0 perspective," Int. J., 2014.

[7] K. Butner, "The smarter supply chain of the future," Strateg. Leadersh., 2010.

[8] L. Wu, X. Yue, A. Jin, and D. C. Yen, "Smart supply chain management: A review and implications for future research," Int. J. Logist. Manag., 2016.

[9] L. Aburto and R. Weber, "Improved supply chain management based on hybrid demand forecasts," Appl. Soft Comput. J., 2007.

[10] R. F. Baumeister and M. R. Leary, "Writing narrative literature reviews," Rev. Gen. Psychol., 1997. 
[11] H. W. Ibrahim, S. Zailani, and K. C. Tan, "A content analysis of global supply chain research," Benchmarking. 2015.

[12] M. Borenstein, L. V. Hedges, J. P. T. Higgins, and H. R. Rothstein, "A basic introduction to fixed-effect and random-effects models for meta-analysis," Res. Synth. Methods, 2010.

[13] S. Seuring and S. Gold, "Conducting content-analysis based literature reviews in supply chain management," Supply Chain Management. 2012.

[14] V. HV, F. Thompson, and O. Tonby, "Understanding ASEAN : Seven things you need to know," McKinsey \& Company. 2014.

[15] D. J. Teece, "Business models, business strategy and innovation," Long Range Plann., 2010 .

[16] 21, "Regional innovation systems: The role of governance in a globalized world," in Regional Studies, 1998.

[17] D. Hew and S. Choudhry, "Roadmap to an ASEAN economic community," Dev. policy Rev., 2007.

[18] M. Rueda Maurer, "Supply chain trade and technological transfer in the ASEAN + 3 region," China Econ. Rev., 2017.

[19] World Economic Forum and Asian Development Bank, ASEAN 4.0: What does the Fourth Industrial Revolution mean for regional economic integration? 2017.

[20] V. F. Martins and C. L. T. Borges, "Active distribution network integrated planning incorporating distributed generation and load response uncertainties," IEEE Trans. Power Syst., 2011.

[21] Z. Lv, J. Xu, X. Zhang, and H. Fan, "Research and application of an intelligent integrated planning and scheduling system," in Proceedings of the 2009 WRI Global Congress on Intelligent Systems, GCIS 2009, 2009.

[22] F. Tian, "An agri-food supply chain traceability system for China based on RFID \& blockchain technology," in 2016 13th International Conference on Service Systems and Service Management, ICSSSM 2016, 2016.

[23] A. H. Glas and F. C. Kleemann, "The Impact of Industry 4.0 on procurement and supply management: A conceptual and qualitative analysis," Int. J. Bus. Manag. Invent. ISSN, 2016.

[24] W. Ding, "Study of smart warehouse management system based on the IOT," in Advances in Intelligent Systems and Computing, 2013.

[25] S. Jabbar, M. Khan, B. N. Silva, and K. Han, “A REST-based industrial web of things' framework for smart warehousing," J. Supercomput., 2018.

[26] M. Arens, "Policy support for and R\&D activities on digitising the European steel industry," Resour. Conserv. Recycl., vol. 143, no. December 2018, pp. 244-250, 2019.

[27] T. Wattanapruttipaisan, "Priority integration sectors in ASEAN: Supply-side implications and options," Asian Dev. Rev., 2007.

[28] Asean, "ASEAN Economic Community," Asean, 2014.

[29] B. N. Bhattacharyay, "Infrastructure for ASEAN Connectivity and Integration," Asean Econ. Bull., 2010. 